\title{
Emerging Market Sovereign Spreads, Global Financial Conditions and U.S. Macroeconomic News
}

\author{
Fatih Özatay \\ Department of Economics \\ TOBB University of Economics and Technology \\ Ankara Turkey \\ Erdal Özmen \\ Department of Economics \\ Middle East Technical University \\ Ankara Turkey \\ Gülbin Şahinbeyoğlu \\ Research and Monetary Policy Department \\ Central Bank of the Republic of Turkey \\ Ankara Turkey
}




\title{
EMERGING MARKET SOVEREIGN SPREADS, GLOBAL FINANCIAL CONDITIONS AND U.S. MACROECONOMIC NEWS ${ }^{1}$
}

\author{
Fatih Özatay ${ }^{\mathrm{a}}$ \\ Erdal Özmen ${ }^{\text {b }}$ \\ Gülbin Şahinbeyoğluc
}

\author{
${ }^{a}$ TOBB University of Economics and Technology, Ankara, Turkey. \\ ${ }^{\mathrm{b}}$ Middle East Technical University, Department of Economics, Ankara, Turkey. \\ ${ }^{\mathrm{c}}$ Central Bank of the Republic of Turkey, Research and Monetary Policy \\ Department, Ankara, Turkey
}

\begin{abstract}
This paper investigates the impact of global financial conditions, US macroeconomic news and domestic macroeconomic fundamentals on the evolution of EMBI spreads for a panel of 18 emerging market (EM) countries using daily data. To this end, we employ not only the conventional panel data estimation procedures but also the recently developed common correlated effects panel mean group method which incorporates heterogeneity by allowing country-specific coefficients whilst accounting for the effects of common global shocks such as contagion. The results strongly suggest that the long-run evolution of EMBI spreads depends on external factors such as changes in global liquidity conditions, risk appetite and crises contagion. Domestic macroeconomic fundamentals proxied by sovereign country ratings are also found to be important in explaining the spreads. The results from panel equilibrium correction models suggest that EMBI spreads respond substantially also to US macroeconomic news and changes in the Federal Reserve's target interest rates. The magnitude and the sign of the effect of US macroeconomic news, however, crucially depend on the state of the US economy, such as the presence of an inflation dominance.
\end{abstract}

Keywords: Bond spreads, Emerging markets, Macroeconomic news

JEL Classification: E43; E58; F36; G14; G15

\footnotetext{
${ }^{1}$ The views expressed in the paper are those of the authors and should not be attributed to their institutions.

Corresponding Author: Gülbin Şahinbeyoğlu, Research and Monetary Policy Department, The Central Bank of Turkey, Istiklal Cad., No. 10, Ulus, 06100, Ankara, Turkey

Phone: +90 312311 2338, e-mail: gulbin.sahinbeyoglu@tcmb.gov.tr
} 


\section{Introduction}

International financial integration presents countries with both opportunities and challenges. One of the basic challenges of the deepening financial integration over the last decades has been the increase in the role of global financial conditions on the macroeconomic fluctuations of emerging market (EM) countries. Calvo $(2002,2005)$, for instance, argue that capital mobility has made EM economies more vulnerable to exogenous shocks coming from global capital markets. In the same vein, according to some recent studies including Neumeyer and Perri (2005), Uribe and Yue (2006), Mackowiak (2007) and Izquierdo, Romero and Talvi (2007), real output fluctuations in EM economies have often been triggered by changes in global financial conditions represented by international interest rates or US monetary policy shocks.

The cost of borrowing faced by EM economies in international financial markets is often represented by emerging market bond index (EMBI) spreads. The EMBI spread, which is the difference between the yields on emerging country sovereign bonds and bonds issued by a government of the industrialized world with identical currency denomination and maturity, is a standard measure of soverign default risk. Movements in EMBI spreads have usually been associated with large business cycle swings in EM economies (Neumeyer and Perri, 2005; Izquierdo et al., 2007). Furthermore, some key financial variables including exchange rates and domestic interest rates tend to be driven also by EMBI spreads as shown by Blanchard (2004) and Favero and Giavazzi (2004) for Brazil and by Özatay (2005) for Turkey.

Understanding the contributions of global (external) and domestic factors on the evolution of EMBI spreads has crucial policy implications. Evidence suggesting that the spreads are mainly driven by domestic macroeconomic fundamentals can be interpreted as "good news" for EM economies implementing sound macroeconomic policies. This is because, such a policy stance should decrease the default risk and thus the spread. However, evidence suggesting that the spreads are mainly driven by global financial conditions and macroeconomic performance of developed countries may imply that EM economies are highly vulnerable to external shocks. A significant increase in EMBI spreads (default risk) due to a tightening cycle in industrial countries, for instance, could lead to a rise in the debt-to-GDP ratio by depreciating the domestic currency and raising domestic interest rates, which has the potential to 
ignite a self-fulfilling prophecy as in the second generation crisis models even in the presence of sustainable domestic macroeconomic fundamentals. Furthermore, based on positive correlations between domestic interest rates, exchange rates and EMBI spreads, Favero and Giavazzi (2004) and Blanchard (2004) argue that the central bank of an EM country may be vulnerable to an exogenous upward shift in the spread as this may lead to domestic currency depreciation and deterioration in inflation expectations. All these do not necessarily reduce the crucial importance of domestic fundamentals even under the case that the spreads are predominantly determined by external conditions as domestic vulnerabilities provide the main magnifying mechanisms through which the impacts of exogenous shocks are transmitted.

The literature on the determinants of EMBI spreads is considerable and growing. One strand of the literature maintains that shocks originating in developed countries are the main drivers of the EMBI spreads and thus emphasises external factors, such as international interest rates, global risk aversion and liquidity conditions (Kamin and Kleist, 1999; Calvo, 2002; García-Herrero and Ortíz, 2006; Gonzales-Rozada and Levy-Yeyati, 2006). A related literature stresses contagion effects of shocks originating in other EM economies on financial portfolios (Broner, et al., 2006) or on EMBI spreads (Kaminsky and Schmukler, 2002). Another strand of the literature focuses on the effects of domestic economic fundamentals, indicating the importance of country default risk or creditworthiness in the determination of the country spreads (Arora and Cerisola, 2001; Kamin, 2002; Çulha et al., 2006).

Financial markets often react to macroeconomic news as documented by a large body of literature the bulk of which are based on the advanced industrial countries. The number of studies considering the impact of daily or intra-daily industrial country macroeconomic news on EM financial asset returns is extremely limited and the recent exceptions include Robitaille and Roush (2006), Wongswan (2006), Andritzky, et al. (2007). This study aims to contribute to this literature also by investigating the impacts of US scheduled macroeconomic announcements and surprises on EMBI spreads. Previous literature typically treats the interpretation of a given piece of macroeconomic news as "good" or "bad", regardless of the state of the economy. Our paper seeks to extend this literature by considering the case that EMBI spreads react differently to a given US macroeconomic news depending on the presence of inflationary concerns in the US economy. 
In this context, this paper aims to investigate the impacts of global financial conditions, US macroeconomic news and domestic macroeconomic fundamentals on the evolution of EMBI spreads for a panel of 18 EM countries by using daily data for the December 31, 1997 - December 31, 2006 period. The literature often employs conventional panel data estimation procedures without providing the individual country estimates, even though these often contain useful information. Therefore, in this study we consider not only the conventional panel data and panel cointegration procedures, but also employ the panel mean group estimation procedure proposed by Pesaran and Smith (1995) that incorporates heterogeneity by allowing for both country-specific intercepts and slopes. Moreover, omitted common variables or global shocks such as contagion may induce cross-section dependence and lead to inconsistent regression coefficient estimates if they are correlated with the explanatory variables. To account for the cross-sectional dependence in the data, we employ the common correlated effects mean group estimator by Pesaran (2006) which is robust in a general non-stationary framework where the regressors and errors share common factors (e.g. global shocks). The empirical modelling contributions of this paper includes panel equilibrium correction estimates of the EMBI spreads which allow us to assess the adjustments to deviations from the long-run equilibrium relationship along with the short-run impact of the stationary US macroeconomic news surprises and changes in the Federal Reserve (FED) target rates.

The plan for the rest of the paper is as follows. The following section presents a brief review of the empirical literature on the determinants of EMBI spreads. This section also argues that the interpretation (and thus the impact) of a macroeconomic news as "good" or "bad" may not be invariant to the state of the economy. Section III is devoted to the empirical analysis of the determinants of EMBI spreads. In section III.1. we report the individual country estimates and the corresponding panel mean group estimation results. Section III.2. takes into account the potential cross-sectional dependence in the data and presents the results for the common correlated effects mean group estimation procedure. Panel cointegration and equilibrium correction mechanisms are also considered in this section. Section III.3. is devoted to the investigation of the impacts of US macroeconomic announcements and surprises on the EMBI spreads. Finally, section IV presents some concluding remarks. 


\section{The Determinants of EMBI Spreads}

A general model for the determinants of sovereign spreads (S) can be defined as

$$
\mathrm{S}_{\mathrm{it}}=\mathrm{c}+\theta \mathrm{X}_{\mathrm{t}}+\Phi \mathrm{Z}_{\mathrm{it}}+\mathrm{u}_{\mathrm{it}}
$$

where $c$ is a constant term, $\mathrm{X}$ and $\mathrm{Z}$ are vectors of foreign and domestic explanatory variables, respectively, $\theta$ and $\Phi$ are the transposes of the corresponding coefficient vectors and $\mathrm{u}$ is the disturbance term. The subscripts $\mathrm{i}$ and $\mathrm{t}$ stand for country and time. In the literature, the set of variables in X contains industrial country (mainly US) interest rates or the FED target rate to proxy global liquidity and some alternative measures to capture global risk appetite or financial conditions. The spread of high yield corporate bonds in developed markets or the volatility implicit in US stock options (VIX) compiled by the Chicago Board Options Exchange are taken as measures of risk appetite of international investors -or alternatively the price of risk (Gonzales-Rozada and Levy-Yeyati, 2006). As argued by Kamin and von Kleist (1999), country spreads are expected to increase with international interest rates since increases in these rates deepen the borrowing country debt burden and the probability of debt default, raising the risk premium. Furthermore, increases in international interest rates can decrease the risk appetite of investors, reducing the demand for risky assets and thus increasing the country spread. It is worth noting that the distinction between "liquidity" and "risk appetite" impacts of international interest rates and high yield spreads may not be very clear as the former implies the latter, or vice versa. Consequently, long-term US interest rates and high yield spreads are often used also to proxy the global risk appetite (Dailami, et al., 2005) and global liquidity (Gonzales-Rozada and Levy-Yeyati, 2006; Fostel and Kaminsky, 2007), respectively.

The results by the empirical literature on the impact of international interest rates appear to be inconclusive. Cline and Barnes (1997), Kamin and von Kleist (1999) and Eichengreen and Mody (2000) suggest that the effect of US interest rates on newissue bond spreads (launch spreads) are either statistically insignificant or theory inconsistent with a negative coefficient. Eichengreen and Mody (2000) justifies the estimated negative interest rate coefficient by arguing that a reduction in the US government bond yield appears to increase the supply of emerging countries' sovereign bonds, thereby raising sovereign spreads. Arora and Cerisola (2001), however, find that the impact of the long-term US interest rates is significantly 
positive when spreads for bonds actively traded in secondary markets are considered instead of launch spreads. Arora and Cerisola (2001) further argue that the FED target rate, which is a direct measure of US monetary policy, tends to influence positively sovereign spreads. Recent research often considers secondary market spreads and finds that both domestic and international factors play a role in their evolution. According to Dailami et al. (2005) the impact of US interest rates and high yield spreads increases significantly with the level of indebtedness of the borrowing country and is not invariant to the contagion effects of crises. This result is consistent with Kaminsky and Schmukler (2002) suggesting that economic fragility, captured by country ratings, makes countries more sensitive to changes in international markets. Kaminsky and Schmukler (2002) find that changes in US short-term interest rates increase country spreads and this impact is more severe in countries with low ratings. The results by Gonzales-Rozada and Levy-Yeyati (2006) suggest that the variability of emerging market spreads is significantly explained by global financial conditions such as the spread of high yield corporate bonds in developed markets, 10-year US Treasury rates and systemic crisis, representing the risk appetite, global liquidity and contagion, respectively.

The set of variables in $\mathrm{Z}$ in (1) contains domestic economic fundamentals indicating default risk or creditworthiness of the country. Country debt, current account deficit, net foreign asset, fiscal balance and gross reserves (all expressed as ratios to the GDP), debt default history, debt service ratios, sovereign credit ratings, terms of trade volatility are among the most commonly employed domestic default indicators. Studies considering country specific variables, including Cline and Barnes (1997), Kamin and von Kleist (1999), Eichengreen and Mody (2000), Arora and Cerisola (2001), Kaminsky and Schmukler (2002), Dailami et al., (2005), Çulha et al. (2006), all find that domestic macroeconomic fundamentals are significant determinants of the sovereign spreads.

Financial markets often react to macroeconomic news as documented by a wide and growing literature, the bulk of which is based on the US or advanced industrial countries. Gürkaynak et al. (2005) find that the US short-term interest rate increases (decreases) when releases that are pro-cyclical (countercyclical) have a higher realized value than expected. The results by Faust et al. (2007) suggest that, stronger than expected US real activity announcements tend to appreciate the dollar and raise 
interest rates in the US. In the same vein, Clarida and Waldman (2007) show that higher than expected inflation appreciates exchange rates in inflation targeting countries implementing a Taylor rule. To date, the number of studies considering the effects of industrial country macroeconomic news using high frequency data on emerging market countries' financial asset returns is very limited and the recent notable exceptions include Robitaille and Roush (2006), Wongswan (2006), Andritzky, et al. (2007). The results by Robitaille and Roush (2006) suggest that US macroeconomic surprises and FOMC interest rate increase announcements prompt an increase in the Brazilian bond yield spread and a decline in the stock price index. Wongswan (2006) find that macroeconomic announcements in the US and Japan have a significant impact on intraday return volatility of Korean and Thai equity markets. Andritzky, et al., (2007) find that macroeconomic announcements basically affect the volatility of emerging market bond spreads by reducing uncertainty. In all these studies, higher than expected real releases are interpreted as "good news" for the strength of the US economy.

However, interpretation of macroeconomic news surprises as "good" or "bad" for a given financial asset variable of interest may not be invariant to the state of the economy. Results of some recent studies based on the US or advanced industrial countries data provide empirical support for this view. For the US, McQueen and Roley (1993) find that, when the economy is strong, the stock market responds negatively to news about higher real economic activity. Boyd et al. (2005) consider the US unemployment data and find that an announcement of rising unemployment is good news for stocks during economic expansions and bad news during economic contractions. Andersen et al. (2007) consider real time interactions between US, German and British stock, bond and foreign exchange markets and find that equity markets react differently to the same news depending on the state of the US economy, with bad macroeconomic news having a positive impact during expansions and negative impact during recessions. 


\section{Empirical Analysis}

EMBI spreads can be specified as determined by domestic macroeconomic fundamentals $(\mathrm{Z})$ and variables representing global financial conditions (X) as already discussed in the context of eq. (1). In this study, we consider daily data which indeed restrict severely the availability of data for domestic macroeconomic variables. Following the literature using high frequency data ${ }^{2}$ we consider country credit ratings as a proxy for the domestic macroeconomic fundamentals. As shown by Cantor and Packer (1996, pp.49), "sovereign ratings effectively summarize and supplement the information contained in macroeconomic indicators". In the same vein, Afonso, Gomes and Rother (2007) find that the core set of variables that are relevant for the determination of the ratings include real GDP, government debt, government effectiveness, external debt, external reserves and default history, which are indeed among the main fundamentals explaining sovereign spreads.

Global financial conditions are proxied by the volatility implicit in US stock options (VIX) compiled by the Chicago Board Options Exchange as a measure of risk appetite of international investors -or alternatively the price of risk (Gonzales-Rozada and Levy-Yeyati, 2006). For robustness, following Blanchard (2004) and Favero and Giavazzi (2004), we also consider the spread of US corporate bonds with a Moody's rating of Baa with a maturity of 10 years over and 10-year US treasuries (HYS) as an alternative measure ${ }^{3}$ of global risk appetite and thus liquidity conditions.

We start by estimating the following equation for each country (i) in our sample:

$$
\mathrm{s}_{\mathrm{it}}=\gamma_{0 \mathrm{i}}+\gamma_{1 \mathrm{i}} \mathrm{rt}_{\mathrm{it}}+\gamma_{2 \mathrm{i}} \mathrm{vix}_{\mathrm{t}}+\mathrm{u}_{\mathrm{it}}
$$

where $\mathrm{s}_{\mathrm{i}}$ is the $\log$ of the EMBI+ spreads provided by JP Morgan ${ }^{4}, \mathrm{rt}_{\mathrm{i}}$ is the $\log$ of sovereign ratings by Standard and Poor's (S\&P) which cover changes in the actual ratings and rating outlooks ${ }^{5}$, and vix is the log of the VIX index. The sample covers

${ }^{2}$ See, Eichengreen and Mody (1998), Kamin and Kleist (1999), Dailami, et al. (2005), GonzalesRozada and Levy-Yeyati (2006) and Andritzky, et al., (2007) for studies using country spreads as a proxy for domestic macroeconomic fundamentals.

${ }^{3}$ The logs of the VIX and HYS variables are found to be both integrated of order one but cointegrated. Consequently, these variables are not considered jointly in our long-run equation specifications.

${ }^{4}$ The EMBI+ index by JP Morgan covers the US dollar and other external currency denominated Brady bonds, loans, Eurobonds, and local market instruments. The details for the index are provided by JPMorgan (2004).

${ }^{5}$ The assignment of numerical values to credit ratings is as in Kamin and Kleist (1999), with 1 being the worst credit risk and 22 the best. Following Gonzales-Rozada and Levy-Yeyati (2006) we interpret the outlook as a five-notch grading scale around the credit rating: positive, positive watch, 
18 emerging market countries (Argentina, Brazil, Bulgaria, Colombia, Ecuador, Egypt, Mexico, Malaysia, Morocco, Panama, Peru, Philippines, Poland, Russia, South Africa, Turkey, Ukraine and Venezuela) for the period from December 31, 1997 to December 29, 2006 (period coverage varies across countries, as reported in Table 1).

\section{III.1. Individual Country and Panel Mean Group Estimations}

The recent empirical studies on the determinants of the country spreads often employ fixed effects estimation procedures to allow heterogeneity between the panel of the countries considered. These methods, however, impose a common slope coefficient disregarding the information provided by the county-specific coefficients. Therefore, in this paper, we employ also the panel mean group (MG) method developed by Pesaran and Smith (1995) which permits heterogeneity in both intercept and slope coefficients. Phillips and Moon (1999) show that the cross-sectional variation in a non-stationary panel may be helpful in obtaining consistent estimates of a long-run average parameter even if there is no time series cointegration at the individual level. As argued by Coakley et al. (2006), this insight justifies the use of the MG procedure which provides consistent estimates for nonstationary, heterogenous panels. Furthermore, standard t-tests for the MG estimator based on the $\mathrm{N}(0,1)$ distribution have reasonably good size properties irrespective of $\mathrm{I}(0)$ or $\mathrm{I}(1)$ errors as shown by Coakley et al. (2006).

To obtain the MG estimators, we first estimate equation (1) for each of the countries. The MG estimator $\left(\hat{\gamma}_{\mathrm{MG}}\right)$ and its standard error $\left(\operatorname{se}\left(\hat{\gamma}_{\mathrm{MG}}\right)\right)$ for $\mathrm{N}$ crosssectional units, are calculated as follows:

$$
\hat{\gamma}_{\mathrm{MG}}=\sum_{i=1}^{N} \hat{\gamma}_{i} / N \text { and } \operatorname{se}\left(\hat{\gamma}_{\mathrm{MG}}\right)=\sigma\left(\hat{\gamma}_{i}\right) / \sqrt{N}
$$

where $\hat{\gamma}_{i}$ and $\sigma\left(\hat{\gamma}_{i}\right)$ are the estimated individual country time-series coefficients and their standard deviations, respectively.

neutral, negative watch, and negative. The outlook -augmented ratings are computed by giving each notch a 0.2 value and adding to the credit rating. We also considered the ratings provided by Institutional Investor as an alternative proxy for domestic factors and obtained virtually the same results presented in this paper. The results with these ratings are reported considering the high correlation between the ratings (Afonso, et al., 2007) and the evidence preferring the S\&P rating (Gande and Parsley, 2005). 


\section{[INSERT TABLE 1 ABOUT HERE]}

Table 1 reports the OLS estimates of the equations for each of the countries. The table reports also the augmented Dickey-Fuller (ADF) statistics to test the nonstationarity of equation residuals $^{6}$ (Engle and Granger, 1987). The results suggest non-rejection of the null of no-cointegration for all the countries except Philliphines. An increase in the price of risk (an increase in vix) substantially and significantly increase the EMBI spreads for each of the countries. Better domestic macroeconomic fundamentals as represented by sovereign ratings leads to a decrease in EMBI spread for all the countries except Philippines and Panama.

The panel MG method yielded the following results (standard errors in parentheses):

$$
\begin{gathered}
\mathrm{s}_{\mathrm{it}}=8.315-2.00 \mathrm{rt}_{\mathrm{it}}+0.998 \mathrm{vix}_{\mathrm{t}} \\
(1.273)(0.577)(0.105)
\end{gathered}
$$

According to the panel MG results, both the domestic fundamentals and global financial conditions are significant in explaining the spreads.

Common global shocks which are not fully represented by the global liquidity condition and risk appetite variables such as VIX or HYS arising from contagion of a crisis in one or a group of EM countries or from shocks originated in financial centers may induce cross-section dependence in the data and thus lead to inconsistent regression coefficient estimates if they are correlated with the explanatory variables. To account for the cross-sectional dependence in the data, we employ the common correlated effects mean group (CCE-MG) estimator by Pesaran (2006). The CCE-MG estimator yields consistent estimates also in the presence of common factors and appears to be the most efficient (Kapetanios and Pesaran, 2007) and robust to alternative hypotheses of non-stationarity of variables (Coakley et al., 2006).

The CCE-MG procedure suggests approximating the linear combinations of the unobserved factors by cross section averages of the dependent and explanatory variables and then estimating the regressions of interest augmented with these cross

\footnotetext{
${ }^{6}$ Table A1 of the Appendix presents the ADF test statistics for the individual country-specific variables. All the country specific variables appear to integrated of order one. The ADF statistics (lag lengths) for vix, $\Delta$ vix, hys and $\Delta$ hys are $-0.70(3),-31.9(2),-0.71(2)$ and $-39.4(1)$, respectively. Accordingly, the ADF statistics in Table 1 can be interpreted as valid to test for the null of no cointegration between the variables in the corresponding equations (Engle and Granger, 1997).
} 
section averages. Therefore, to obtain the CCE-MG estimator, we estimate the following equation for each country (i):

$$
\mathrm{s}_{\mathrm{it}}=\gamma_{0 \mathrm{i}}+\gamma_{1 \mathrm{i}} \mathrm{rt}_{\mathrm{it}}+\gamma_{2 \mathrm{i}} \mathrm{vix_{ \textrm {t } }}+\mathrm{c}_{1 \mathrm{i}} \mathrm{m} \_\mathrm{rt} \mathrm{t}_{\mathrm{t}}+\mathrm{c}_{2 \mathrm{i}} \mathrm{m} \_\mathrm{s}_{\mathrm{t}}+\mathrm{u}_{\mathrm{it}}
$$

In (3) m_rt and m_s denote the cross-sectional means of the ratings (rt) and EMBI spreads (s). Note that, the coefficients of the cross-sectional means (CSMs) do not need to have any economic meaning as their augmentation simply aims to improve the coefficient estimates of interest. However, in our specific case, the CSMs may be attributed to contain also some important information for the evolution of our main variable of interest -EMBI spreads. The effect of common global shocks such as contagion may plausibly be argued to be represented mainly by the CSMs of EMBI spreads, therefore we expect the estimated $c_{2 i}$ to be positive. To the extend that, the ratings are determined solely by domestic macroeconomic fundamentals, the impact of the CSMs of the ratings for the spread of the country may be ambiguous.

Table 2 reports the estimation results for equation (3) for each of the countries. The ADF test results suggest that all the equations except for Philliphines can be interpreted as representing the long-run equilibrium relationships. The results are essentially the same as those reported in Table 1 except the cases that the country rating variable coefficients become positive for S. Africa and insignificant for Egypt and Poland whilst vix coefficients become negative for Argentina, Malaysia and Morocco when the equations are augmented with the CSMs of ratings and spreads.

\section{[INSERT TABLE 2 ABOUT HERE]}

The common correlated effects mean group (CCE-MG) method yielded the following results (standard errors in parentheses):

$$
\begin{aligned}
& \mathrm{s}_{\mathrm{it}}=2.677-1.039 \mathrm{rt} \mathrm{it}_{\mathrm{t}}+0.142 \mathrm{vix}_{\mathrm{t}}+0.773 \mathrm{~m} \_\mathrm{s} \mathrm{t}+0.239 \mathrm{~m} \_\mathrm{rt}_{\mathrm{t}} \\
& \begin{array}{llll}
(1.330) & (0.346) & (0.056) & (0.075)
\end{array}
\end{aligned}
$$

All the coefficients except that for m_rt are strongly significant and theory-consistent. The statistical insignificance of the m_rt coefficient may not be unexpected as the impact of the CSM ratings on the individual country spreads may be negative or positive potentially depending on their relative strength of domestic fundamentals to the rest of the countries. The contagion impact of crises or financial turbulence in one or a group of EM countries appears to be an important determinant of EMBI spreads. 
Consistent with an argument that both the vix and CSM spreads may contain the impact of global financial shocks, the coefficient of vix $x_{t}$ considerably decreases with the inclusion of $\mathrm{m} \_\mathrm{s}_{\mathrm{t}}$. Consequently, the vix $\mathrm{x}_{\mathrm{t}}$ coefficient now represents the net impact of global financial conditions which is not fully represented by $\mathrm{m}_{-} \mathrm{s}_{\mathrm{t}}$, or vice versa. The overall impact of the external factors represented by vix and $\mathrm{m}_{-} \mathrm{s}_{\mathrm{t}}$ appears to be comparable with the effect of domestic macroeconomic fundamentals. The significance of the external factors arising from the interrelated global liquidity conditions, risk appetite and crises contagion is consistent with the recent findings of Gonzales-Rozada and Levy-Yeyati (2006) suggesting that "a large fraction of the variability of emerging market bond spreads is explained by the evolution of global factors" and thus EM countries "do remain vulnerable to sudden shift in financial market conditions".

To check the robustness of our results, we consider also high yield spread (HYS) as an alternative measure of global risk appetite and thus liquidity conditions. Following following Blanchard (2004) and Favero and Giavazzi (2004), we define HYS as the spread of US corporate bonds with a Moody's rating of Baa with a maturity of 10 years over and 10-year US treasuries (HYS). Table A2 and Table A3 in the Appendix respectively reports individual country estimates of equations (2) and (3) with hys instead of vix, The results are virtually the same with those reported in Tables 1 and 2. The panel mean group (PMG) and the common correlated effects panel (CCE-MG) method yielded the following results:

$$
\mathrm{s}_{\mathrm{it}}=15.133-3.908 \mathrm{rt}_{\mathrm{it}}+1.129 \mathrm{hys}_{\mathrm{t}}
$$

$$
\text { (2.834) (1.157) (0.205) }
$$

and

$$
\begin{aligned}
& \mathrm{s}_{\mathrm{it}}=3.049-1.1270 \mathrm{rt}_{\mathrm{it}}+0.225 \mathrm{hys}_{\mathrm{t}}+0.793 \mathrm{~m} \_\mathrm{s}_{\mathrm{t}}+0.283 \mathrm{~m} \_\mathrm{rt}_{\mathrm{t}} \\
& \begin{array}{llll}
(1.344) & (0.409) & \text { (0.106) } & \text { (0.076) }
\end{array}
\end{aligned}
$$

The magnitudes of the estimated coefficients for hys in the equations are only slightly and insignificantly greater than those with vix, suggesting the robustness of our result to the use of an alternative indicator for global financial conditions. The coefficient of rt considerably increases in the equations with hys. Furthermore, the cross-sectional means of the ratings (m_rt) become statistically significant in the CCE-MG equation with hys. However, the main message from the use of these two alternative global 
indicators, namely the crucial importance of external factors in determining the EMBI spreads, remains empirically valid and robust.

\section{III.2. Panel Cointegration and ECM Estimations}

The recent literature including Gonzales-Rozada and Levy-Yeyati (2006) often employs panel data estimation procedures in investigating the determinants of EMBI spreads. Equation (4.1) in Table 4 presents the results of the cross-section fixed effects regression for our unbalanced panel data of 18 countries. Both the rt and vix variables have the expected coefficient signs and are statistically significant. Compared to the MG and CCE-MG estimations, the absolute magnitude of the estimated coefficients appears to be smaller for the rt coefficient and larger for the vix coefficient. However, the basic idea that the EMBI spreads are largely determined by global financial conditions along with domestic fundamentals remains to be strongly supported. For a robustness check, we consider also high yield spread (HYS) as an alternative measure of global risk appetite and thus liquidity conditions. Equation (4.2) in Table 4 presents the results with hys instead of vix. The results from (4.2) are essentially the same with those from (4.1). In Equation (4.3) we consider vix and hys jointly. Accordingly, the inclusion of hys does not affect the magnitude of the estimated coefficient for vix significantly. The coefficient of hys, on the other hand, decreases substantially with the inclusion of vix. This evidence may lend a support to the view that the use of the VIX index alone may not lead to a significant information loss in our analysis. Equation (4.4) reports the results of the Pesaran (2006) panel common correlated effects procedure which are obtained by the fixed effects estimation of (4.1) augmented by cross section averages of $\mathrm{rt}_{\mathrm{it}}$ and $\mathrm{s}_{\mathrm{it}}$ ( $\mathrm{m} \_\mathrm{rt}$ and $\mathrm{m} \_\mathrm{s}$ ). Consistent with the PMG and CCE-MG results obtained earlier from individual country estimates, the vix coefficient declines considerably with the inclusion of $\mathrm{m} \_s$.

\section{[INSERT TABLES 3 and 4 ABOUT HERE]}

The results of the panel unit root tests presented in Table 5 suggest that all the variables in our panel data regressions are integrated of order one (I(1)). Consequently, we need to test whether these I(1) variables are not cointegrated. To this end, we consider Engle and Granger (1987) based procedures and test whether the residuals from the static regressions are not stationary. All the tests suggest the 
stationarity of the equation residuals and thus the cointegration of the variables. Consequently, the equations represent long-equilibrium relationship and by the Granger representation theorem there is an equilibrium correction mechanism (ECM) for the evolution of EMBI spreads.

To estimate the panel ECM (PECM) representation which allows us to assess the adjustment mechanism to a deviation from the long-run equilibrium relationship along with the short-run dynamics, we first consider the following specification:

$$
\Delta \mathrm{s}_{\mathrm{it}}=\mathrm{b}_{0 \mathrm{i}}+\alpha \mathrm{ec}_{\mathrm{t}-1}+\mathrm{b}_{1} \Delta \mathrm{s}_{\mathrm{it}-1}+\mathrm{c}_{1} \Delta \mathrm{rt}_{\mathrm{it}}+\mathrm{c}_{2} \Delta \mathrm{rt}_{\mathrm{it}-1}+\mathrm{d}_{1} \Delta \mathrm{vix}_{\mathrm{t}}+\mathrm{d}_{2} \Delta \mathrm{vix} \mathrm{x}_{\mathrm{t}-1}+\mathrm{u}_{\mathrm{it}}
$$

where ec (equilibrium correction term) are the stationary residuals from equation 4.1 in Table 4. Considering the low sample variability of rt, we set the lag length as 2 for the general Autoregressive Distributed Lag (ARDL) relationship, a reparameterisation of which gives (4). Equation (5.1) in Table 5 presents the estimation results. Accordingly, the equilibrium correction in the long-run evolution of the EMBI spreads appears to be significant, and considering the fact that the data are daily, the adjustment towards equilibrium is relatively rapid (around six months). The short-run impact of changes in the global financial conditions as represented by the $\Delta$ vix coefficient appears to be significant.

\section{[INSERT TABLE 5 ABOUT HERE]}

\section{III.3. US Macroeconomic News and EMBI Spreads}

Financial markets often react to US macroeconomic news as documented by a large body of literature the bulk of which are based on the advanced industrial countries. In this section, we proceed with investigating the impacts of U.S. scheduled macroeconomic announcements and surprises on EMBI spreads. To this end, we consider nine major U.S. regularly scheduled macroeconomic announcements basically concerning real activity (non-farm payroll employment NFP, retail sales RS, capacity utilization CU), consumption (new home sales NHS), forward looking (manufacturing index MAN, consumer confidence CCONF, leading indicators LEAD) and prices (core consumer price index CPI, core producer price index PPI).

We measure expectations on U.S. macroeconomic fundamentals using the median market forecasts provided by Bloomberg. For a given macroeconomic variable $\mathrm{M}_{\mathrm{t}}$, the "news" or "surprise" is defined as the difference between the actual 
macroeconomic announcement $\left(\mathrm{M}_{\mathrm{t}}^{\mathrm{a}}\right)$ and the survey expectations $\left(\mathrm{M}_{\mathrm{t}}^{\mathrm{e}}\right)$. The units of measurement differ across the variables, therefore, following Balduzzi et al. (2001) and Andersen et al. (2003), we use standardized news for the ease of interpretation. The standardized news for $\mathrm{M}_{\mathrm{t}}\left(\mathrm{M}_{\mathrm{t}}^{\mathrm{s}}\right)$ is obtained by dividing each macroeconomic news variable $\left(\mathrm{M}_{\mathrm{t}}^{\mathrm{a}}-\mathrm{M}_{\mathrm{t}}^{\mathrm{e}}\right)$ by its sample standard deviation. As the sample standard deviation is constant for each of the variables, such a standardization does not affect the statistical properties of the estimators.

\section{[INSERT TABLE 6 ABOUT HERE]}

Table 6 lists the US macroeconomic announcements and reports the individual univariate statistical properties of the data using the ADF tests. All the forecast errors or surprises (actual less expected) and five of the series (NFP, RS, LEAD, CPI, PPI), both announced (realized) and expected, appear to be zero-mean stationary. The order of integration for the expected and realised CU, NHS, MAN and CCONF is found to be unity. For these variables, the expected and realized values appear to be cointegrated with a unitary coefficient as suggested by the ADF tests for the surprises. Consistent with the rational expectations hypothesis, the stationarity of the forecast errors support the lack of a systematic bias in the surprises (Edison, 1997).

The stationarity of the news variables precludes them to be considered for a cointegration analysis. As a plausible alternative, we augment the PECM given by equation (4) with the US macroeconomic news variables to obtain:

$$
\begin{gathered}
\Delta \mathrm{s}_{\mathrm{it}}=\mathrm{b}_{0 \mathrm{i}}+\alpha \mathrm{ec}_{\mathrm{t}-1}+\mathrm{b}_{1} \Delta \mathrm{s}_{\mathrm{it}-1}+\mathrm{c}_{1} \Delta \mathrm{rt}_{\mathrm{it}}+\mathrm{c}_{2} \Delta \mathrm{rt}_{\mathrm{it}-1}+\mathrm{d}_{1} \Delta \mathrm{vix}_{\mathrm{t}}+\mathrm{d}_{2} \Delta \mathrm{vix}_{\mathrm{t}-1} \\
\mathrm{e}_{1} \Delta \mathrm{ftr}_{\mathrm{t}}+\mathrm{e}_{2} \Delta \mathrm{ftr}_{\mathrm{t}-1}+\sum \mathrm{f}_{\mathrm{j}} \mathrm{news}_{\mathrm{jt}}+\mathrm{u}_{\mathrm{it}}
\end{gathered}
$$

where news ${ }_{\mathrm{j}}$ is the $\mathrm{j}^{\text {th }}$ news. Note that, equation (5) contains also changes in the U.S. federal funds target rate ( $\Delta \mathrm{ftr}$ ) which is found to be stationary (Table 5). We suppose that the variables proxying global financial conditions such as VIX and HYS may contain also the impacts of the US monetary policy changes. The inclusion of the FED target rate, thus, maintains that changes in the US monetary policy may have an impact on EMBI spreads (Arora and Cerisola, 2001) in the short-run apart from those already captured by VIX or HYS in the long-run specifications.

Equation (5.2) in Table 5 presents the results. As expected, an increase in the FED target rates leads to an increase in the EMBI spreads in the short-run. The results 
also suggest that the spreads respond to US macroeconomic news about non-farm payroll employment (NFP), retail sales (RS), new home sales (NHS), ISM manufacturing (MAN) and consumer confidence $(\mathrm{CCONF})^{7}$. The negative estimated coefficients of the news variables lend a support to the view that stronger-thanexpected announcements for U.S. real activity lead EM country spreads to decline in the short-run. It may be plausible to expect that EM country spreads to decline with a stronger global economy. However, such an interpretation maintains that higher than expected real releases are always good news for the strength of the US economy.

The literature often maintains that the interpretation of a given macroeconomic news as "good" or "bad" is invariant to the state of the economy. Under a positive inflation gap during which inflation tends to be higher than the long-run or targeted inflation, for instance, a higher than expected real activity may be interpreted as the economy is over heating and thus a "bad news" for monetary policy causing concerns about higher interest rates. Therefore, to consider the state of the US economy, we define the periods of positive deviations of inflation (based on seasonally adjusted core CPI series) from its Hodrick-Prescott detrended cyclical component as periods of "inflation dominance". We define a dummy variable D taking unity when the observation belongs to the "inflation dominance" period and zero otherwise. We then interact the news variables with $\mathrm{D}$, to obtain

$$
\begin{gathered}
\Delta \mathrm{s}_{\mathrm{it}}=\mathrm{b}_{0 \mathrm{i}}+\alpha \mathrm{ec}_{\mathrm{t}-1}+\mathrm{b}_{1} \Delta \mathrm{s}_{\mathrm{it}-1}+\mathrm{c}_{1} \Delta \mathrm{rt}_{\mathrm{it}}+\mathrm{c}_{2} \Delta \mathrm{rt}_{\mathrm{it}-1}+\mathrm{d}_{1} \Delta \mathrm{vix}_{\mathrm{t}}+\mathrm{d}_{2} \Delta \mathrm{vix}_{\mathrm{t}-1} \\
\mathrm{e}_{1} \Delta \mathrm{ftr}_{\mathrm{t}}+\mathrm{e}_{2} \Delta \mathrm{ftr}_{\mathrm{t}-1}+\sum \mathrm{f}_{\mathrm{j}} \text { news }_{\mathrm{jt}}+\sum \mathrm{g}_{\mathrm{j}} \text { D.news }_{\mathrm{jt}}+\mathrm{u}_{\mathrm{it}}
\end{gathered}
$$

In equation (6), the coefficient of news ${ }_{j}\left(f_{j}\right)$ now gives the impact of the $j^{\text {th }}$ news when there is no inflation dominance whilst $\left(\mathrm{g}_{\mathrm{j}}\right)$ gives the change in the coefficient in the period of inflationary pressures on the economy. We expect the coefficient of D.news $_{\mathrm{j}}\left(\mathrm{g}_{\mathrm{j}}\right)$ to be positive as "positive news" or "stronger-than-expected macroeconomic announcements" may now mean that the economy is over heating rather than reflecting the strength of the US economy.

\footnotetext{
7 The news about leading indicators (LEAD), capacity utilization (CU) and prices (CPI and PPI) are found to be jointly and individually insignificant in all the specifications reported in Table 5. The Likelihood Ratio (LR) test that these variables are jointly redundant in equation (5.1), for instance, yielded 5.26 with $\mathrm{p}=0.26$.
} 
According to the results reported by equation (5.3) in Table 5, all positive news surprises, except CCONF, significantly decrease EMBI spreads in the absence of an inflation dominance in the US economy. Positive surprises about a leading indicator variable consumer confidence CCONF, appears to be good news for the strength of the economy especially when there is an inflationary pressure. The response of EMBI spreads to positive news about the retail sales (RS), on the other hand, tends to be the same across the periods. Stronger-than-expected announcements for non-farm payroll employment (NFP), manufacturing (MAN) and new home sales (NHS) all lead to a significant decrease in the EMBI spreads during the periods of relatively lower inflation rates. Inflation dominance, however, tends to reduce this impact substantially. In the case of NHS, positive surprises can be interpreted as good news for EMBI spreads when there is no inflation dominance but turns out to be bad news otherwise. All these results suggest that investors' response to news is not invariant to the state of the economy.

\section{Concluding Remarks}

"When it rains, it pours" according to a recent study by Kaminsky, Reinhart and Vegh (2004) investigating the impact of capital flows to EM countries. In the same vein, according to Calvo (2002, 2005), with international financial integration, EM economies become more vulnerable to exogenous shocks coming from global capital markets which is referred to as "globalization hazard". Consequently, both capital flows to EM economies and their sudden stops leading to financial crises during the last decade exhibit an important degree of "globalization hazard" (Calvo, 2005). According to Uribe and Yue (2006), the price level and real output in a typical emerging market respond to US monetary policy shocks by more than the price level and real output in the US itself. Therefore, it may be argued that "when the U.S. sneezes, emerging markets catch a cold". Our results, strongly suggesting that the long-run evolution of EMBI spreads crucially depends on external factors arising from the interrelated global liquidity conditions, risk appetite, crises contagion and US macroeconomic news provide a further support to the argument that real output fluctuations in EM economies have been significantly triggered by global financial conditions. 
The crucial importance of exogenous global factors in the determination of interest rates that EM countries face in international financial markets does not necessarily relegate the importance of domestic macroeconomic fundamentals. The significance of the fundamentals in the long run evolution of the spreads simply imply that a strong macroeconomic policy stance improving domestic fundamentals will be decreasing the default risk and hence the cost of borrowing. The domestic fundamentals are important even under the case that the spreads are predominantly determined by external conditions as they provide the main magnifying mechanisms through which the impacts of exogenous shocks are transmitted. 
Table 1. The Determinants of EMBI Spreads: Individual Country Estimates

\begin{tabular}{|c|c|c|c|c|c|c|c|c|}
\hline Country & constant & rt & vix & $\mathbf{R}^{2}$ & $\operatorname{ADF}(\mathbf{l})$ & $\mathbf{M}_{\mathrm{RT}}$ & $\sigma_{\mathrm{RT}}$ & $\mathbf{N}$ \\
\hline Argentina & $\begin{array}{l}5.513 * * \\
(0.057)\end{array}$ & $\begin{array}{l}-0.570 * * \\
(0.003)\end{array}$ & $\begin{array}{l}0.723 * * \\
(0.019)\end{array}$ & 0.928 & $-4.68(8)^{++}$ & 5.74 & 4.83 & 2246 \\
\hline Brazil & $\begin{array}{l}10.958 * * \\
(0.197)\end{array}$ & $\begin{array}{l}-3.266 * * \\
(0.073)\end{array}$ & $\begin{array}{l}0.973 * * \\
(0.016)\end{array}$ & 0.872 & $-6.65(0)^{++}$ & 9.59 & 0.70 & 2246 \\
\hline Bulgaria & $\begin{array}{l}14.238 * * \\
(0.144)\end{array}$ & $\begin{array}{l}-4.109 * * \\
(0.038)\end{array}$ & $\begin{array}{l}0.411 * * \\
(0.021)\end{array}$ & 0.949 & $-4.10(1)^{++}$ & 11.16 & 2.13 & 2022 \\
\hline Colombia & $\begin{array}{l}4.930 * * \\
(0.307)\end{array}$ & $\begin{array}{l}-0.867 * * \\
(0.122)\end{array}$ & $\begin{array}{l}1.109 * * \\
(0.017)\end{array}$ & 0.721 & $-4.87(1)^{++}$ & 11.46 & 0.80 & 1893 \\
\hline Ecuador & $\begin{array}{l}4.976^{* *} \\
(0.055)\end{array}$ & $\begin{array}{l}-0.501 * * \\
(0.022)\end{array}$ & $\begin{array}{l}0.968 * * \\
(0.013)\end{array}$ & 0.788 & $-6.20(0)^{++}$ & 6.07 & 0.79 & 1600 \\
\hline Egypt & $\begin{array}{l}9.778 * * \\
(1.518)\end{array}$ & $\begin{array}{l}-4.019 * * \\
(0.617)\end{array}$ & $\begin{array}{l}1.780 * * \\
(0.028)\end{array}$ & 0.781 & $-4.97(2)^{++}$ & 12.34 & 0.52 & 1143 \\
\hline Mexico & $\begin{array}{l}15.006 * * \\
(0.149)\end{array}$ & $\begin{array}{l}-4.504 * * \\
(0.049)\end{array}$ & $\begin{array}{l}0.688^{*} * \\
(0.011)\end{array}$ & 0.934 & $-7.06(0)^{++}$ & 12.66 & 0.97 & 2246 \\
\hline Malaysia & $\begin{array}{l}13.813^{* *} \\
(0.500)\end{array}$ & $\begin{array}{l}-3.975 * * \\
(0.164)\end{array}$ & $\begin{array}{l}0.570 * * \\
(0.023)\end{array}$ & 0.830 & $-5.53(0)^{++}$ & 14.89 & 1.15 & 725 \\
\hline Morocco & $\begin{array}{l}22.016^{* *} \\
(0.778)\end{array}$ & $\begin{array}{l}-8.199 * * \\
(0.291)\end{array}$ & $\begin{array}{l}1.151^{* *} \\
(0.032)\end{array}$ & 0.796 & $-4.87(1)^{++}$ & 11.16 & 0.42 & 2185 \\
\hline Panama & $\begin{array}{l}2.875 * * \\
(0.181)\end{array}$ & $\begin{array}{l}0.335^{* * *} \\
(0.081)\end{array}$ & $\begin{array}{l}0.734^{* *} \\
(0.012)\end{array}$ & 0.704 & $-4.88(2)^{++}$ & 11.32 & 0.57 & 2246 \\
\hline Peru & $\begin{array}{l}6.051 * * \\
(0.297)\end{array}$ & $\begin{array}{l}-1.604 * * \\
(0.113)\end{array}$ & $\begin{array}{l}1.257^{* *} \\
(0.018)\end{array}$ & 0.796 & $-6.38(1)^{++}$ & 10.69 & 0.56 & 2246 \\
\hline Philippines & $\begin{array}{l}3.962 * * \\
(0.225)\end{array}$ & $\begin{array}{l}0.224 \\
(0.117)\end{array}$ & $\begin{array}{l}0.517^{* * *} \\
(0.026)\end{array}$ & 0.389 & $-2.59(0)$ & 11.22 & 0.79 & 2102 \\
\hline Poland & $\begin{array}{l}6.223^{* *} \\
(0.538)\end{array}$ & $\begin{array}{l}-2.314 * * \\
(0.188)\end{array}$ & $\begin{array}{l}1.624 * * \\
(0.025)\end{array}$ & 0.726 & $-5.46(2)^{++}$ & 14.69 & 0.63 & 2246 \\
\hline Russia & $\begin{array}{l}1.014 * * \\
(0.116)\end{array}$ & $\begin{array}{l}-0.315 * * \\
(0.007)\end{array}$ & $\begin{array}{l}1.919 * * \\
(0.038)\end{array}$ & 0.768 & $-4.38(1)^{++}$ & 8.40 & 4.93 & 2246 \\
\hline S. Africa & $\begin{array}{l}11.506^{* *} \\
(0.454)\end{array}$ & $\begin{array}{l}-3.242 * * \\
(0.155)\end{array}$ & $\begin{array}{l}0.674 * * \\
(0.022)\end{array}$ & 0.811 & $-4.69(2)^{++}$ & 13.35 & 1.00 & 1010 \\
\hline Turkey & $\begin{array}{l}8.113 * * \\
(0.154)\end{array}$ & $\begin{array}{l}-1.803 * * \\
(0.046)\end{array}$ & $\begin{array}{l}0.636^{* *} \\
(0.021)\end{array}$ & 0.858 & $-4.47(2)^{++}$ & 8.55 & 1.21 & 1851 \\
\hline Ukraine & $\begin{array}{l}6.942 * * \\
(0.376)\end{array}$ & $\begin{array}{l}-1.689 * * \\
(0.130)\end{array}$ & $\begin{array}{l}0.853^{* *} \\
(0.038)\end{array}$ & 0.730 & $-4.27(1)^{++}$ & 8.83 & 0.90 & 1252 \\
\hline Venezuella & $\begin{array}{l}2.666 * * \\
(0.062)\end{array}$ & $\begin{array}{l}-0.134 * * \\
(0.012)\end{array}$ & $\begin{array}{l}1.383^{* *} \\
(0.012)\end{array}$ & 0.695 & $-5.97(0)^{++}$ & 7.98 & 1.42 & 2246 \\
\hline \multicolumn{9}{|c|}{$\begin{array}{l}\text { Notes: t-ratios in parentheses. }(*) \text { and }(* *) \text { denote significance at the } 5 \% \text { and } 1 \% \text { level, respectively. } \\
\text { ADF(l) are the ADF tests results for the residuals of the corresponding equation with the lag length (l) } \\
\text { chosen by the Akaike Information Criteria (AIC). For the ADF tests }\left(^{++}\right) \text {denotes the rejection of the } \\
\text { unit root null hypothesis at the } 5 \% \text { level. } \mathrm{M}_{\mathrm{RT}} \text { is the sample mean of the outlook augmented rating and } \sigma_{\mathrm{I}} \\
\text { standard deviation. } \mathrm{N} \text { is the effective number of observations. }\end{array}$} \\
\hline
\end{tabular}


Table 2. The Determinants of EMBI Spreads: Individual Country Estimates with CCE

\begin{tabular}{|c|c|c|c|c|c|c|c|}
\hline Country & constant & rt & vix & $\mathbf{m} \_\mathbf{s}$ & m_rt & $\mathbf{R}^{2}$ & ADF(l) \\
\hline Argentina & $\begin{array}{l}4.422 * * \\
(0.190\end{array}$ & $\begin{array}{l}-0.590 * * \\
(0.004)\end{array}$ & $\begin{array}{l}-0.191 * * \\
(0.036)\end{array}$ & $\begin{array}{l}0.615 * * \\
(0.025)\end{array}$ & $\begin{array}{l}0.050 \\
(0.060)\end{array}$ & 0.948 & $-5.25(8)^{++}$ \\
\hline Brazil & $\begin{array}{l}8.807 * * \\
(0.203)\end{array}$ & $\begin{array}{l}-2.578 * * \\
(0.097)\end{array}$ & $\begin{array}{l}0.516 * * \\
(0.024)\end{array}$ & $\begin{array}{l}0.356^{* *} \\
(0.014)\end{array}$ & $\begin{array}{l}-0.087 * * \\
(0.041)\end{array}$ & 0.901 & $-4.70(0)^{++}$ \\
\hline Bulgaria & $\begin{array}{l}7.737 * * \\
(0.344)\end{array}$ & $\begin{array}{l}-3.055^{* *} \\
(0.069)\end{array}$ & $\begin{array}{l}0.065^{* * *} \\
(0.027)\end{array}$ & $\begin{array}{l}0.626^{* * *} \\
(0.032)\end{array}$ & $\begin{array}{l}0.726^{* *} \\
(0.039)\end{array}$ & 0.960 & $-4.52(0)^{++}$ \\
\hline Colombia & $\begin{array}{l}\text { 7.352** } \\
(0.184)\end{array}$ & $\begin{array}{l}-1.509 * * \\
(0.065)\end{array}$ & $\begin{array}{l}0.118^{* * *} \\
(0.019)\end{array}$ & $\begin{array}{l}0.578^{* *} \\
(0.012)\end{array}$ & $\begin{array}{l}-0.639^{* *} \\
(0.027)\end{array}$ & 0.922 & $-4.92(3)^{++}$ \\
\hline Ecuador & $\begin{array}{l}3.606 * * \\
(0.094)\end{array}$ & $\begin{array}{l}-0.181 * * \\
(0.007)\end{array}$ & $\begin{array}{l}0.258^{* * *} \\
(0.020)\end{array}$ & $\begin{array}{l}0.502 * * \\
(0.014)\end{array}$ & $\begin{array}{l}-0.045 \\
(0.029)\end{array}$ & 0.898 & $-4.61(0)^{++}$ \\
\hline Egypt & $\begin{array}{l}-4.080^{*} \\
(1.593)\end{array}$ & $\begin{array}{l}-0.194 \\
(0.744)\end{array}$ & $\begin{array}{l}0.482^{* *} \\
(0.063)\end{array}$ & $\begin{array}{l}1.174 * * \\
(0.064)\end{array}$ & $\begin{array}{l}0.638^{*} \\
(0.147)\end{array}$ & 0.848 & $-4.38(0)^{++}$ \\
\hline Mexico & $\begin{array}{l}7.751 * * \\
(0.187) \\
\end{array}$ & $\begin{array}{l}-2.696^{* *} \\
(0.050)\end{array}$ & $\begin{array}{l}0.122 * * \\
(0.014)\end{array}$ & $\begin{array}{l}0.586^{* * *} \\
(0.012)\end{array}$ & $\begin{array}{l}0.365^{* *} \\
(0.018)\end{array}$ & 0.968 & $-5.33(0)^{++}$ \\
\hline Malaysia & $\begin{array}{l}1.155^{*} \\
(0.627) \\
\end{array}$ & $\begin{array}{l}-0.365^{* *} \\
(0.149) \\
\end{array}$ & $\begin{array}{l}-0.252 * * \\
(0.028) \\
\end{array}$ & $\begin{array}{l}1.139 * * \\
(0.029)\end{array}$ & $\begin{array}{l}-0.725^{* *} \\
(0.280) \\
\end{array}$ & 0.945 & $-6.09(0)^{++}$ \\
\hline Morocco & $\begin{array}{l}2.631^{* *} \\
(0.408) \\
\end{array}$ & $\begin{array}{l}-2.003 * * \\
(0.161) \\
\end{array}$ & $\begin{array}{l}-0.185^{* *} \\
(0.019) \\
\end{array}$ & $\begin{array}{l}1.268^{* * *} \\
(0.013)\end{array}$ & $\begin{array}{l}0.339 * * \\
(0.027) \\
\end{array}$ & 0.965 & $-6.16(2)^{++}$ \\
\hline Panama & $\begin{array}{l}5.319 * * \\
(0.146)\end{array}$ & $\begin{array}{l}-0.758 * * \\
(0.081)\end{array}$ & $\begin{array}{l}0.038^{* *} \\
(0.013)\end{array}$ & $\begin{array}{l}0.485^{* *} \\
(0.011)\end{array}$ & $\begin{array}{l}-0.288^{* *} \\
(0.019)\end{array}$ & 0.910 & $-4.16(1)^{++}$ \\
\hline Peru & $\begin{array}{l}5.459 \\
(0.153) \\
\end{array}$ & $\begin{array}{l}-1.902 * * \\
(0.062)\end{array}$ & $\begin{array}{l}0.084 * * \\
(0.018) \\
\end{array}$ & $\begin{array}{l}0.768 * * \\
(0.010)\end{array}$ & $\begin{array}{l}0.067 * * \\
(0.022)\end{array}$ & 0.946 & $-5.05(0)^{++}$ \\
\hline Philippines & $\begin{array}{l}9.963 * * \\
(0.295)\end{array}$ & $\begin{array}{l}-3.120 * * \\
(0.148)\end{array}$ & $\begin{array}{l}0.096^{* * *} \\
(0.027)\end{array}$ & $\begin{array}{l}0.662^{* * *} \\
(0.024)\end{array}$ & $\begin{array}{l}-0.270 * * \\
(0.035)\end{array}$ & 0.573 & $-2.31(0)$ \\
\hline Poland & $\begin{array}{l}-4.801 * * \\
(0.491)\end{array}$ & $\begin{array}{l}0.207 \\
(0.149)\end{array}$ & $\begin{array}{l}0.235^{* *} \\
(0.035)\end{array}$ & $\begin{array}{l}1.084 * * \\
(0.023)\end{array}$ & $\begin{array}{l}0.829 * * \\
(0.0 .46)\end{array}$ & 0.861 & $-5.77(0)^{++}$ \\
\hline Russia & $\begin{array}{l}-5.605^{* *} \\
(0.173)\end{array}$ & $\begin{array}{l}-0.523 * * \\
(0.009)\end{array}$ & $\begin{array}{l}-0.074 \\
(0.044)\end{array}$ & $\begin{array}{l}1.356^{* * *} \\
(0.031)\end{array}$ & $\begin{array}{l}2.232 * * \\
(0.053)\end{array}$ & 0.919 & $-4.55(0)^{++}$ \\
\hline S. Africa & $\begin{array}{l}-10.16^{* *} \\
(0.837)\end{array}$ & $\begin{array}{l}2.932 * * \\
(0.205)\end{array}$ & $\begin{array}{l}0.162 * * \\
(0.023)\end{array}$ & $\begin{array}{l}1.074 * * \\
(0.035)\end{array}$ & $\begin{array}{l}0.319^{* *} \\
(0.047)\end{array}$ & 0.903 & $-5.03(1)^{++}$ \\
\hline Turkey & $\begin{array}{l}5.765^{* *} \\
(0.181)\end{array}$ & $\begin{array}{l}-1.650 * * \\
(0.040)\end{array}$ & $\begin{array}{l}0.159 * * \\
(0.027)\end{array}$ & $\begin{array}{l}0.423 * * \\
(0.017)\end{array}$ & $\begin{array}{l}0.411^{* *} \\
(0.036)\end{array}$ & 0.895 & $-4.65(3)^{++}$ \\
\hline Ukraine & $\begin{array}{l}-1.068 \\
(0.660)\end{array}$ & $\begin{array}{l}-0.708 \\
(0.208)\end{array}$ & $\begin{array}{l}0.622 * * \\
(0.042)\end{array}$ & $\begin{array}{l}0.590 * * \\
(0.042)\end{array}$ & $\begin{array}{l}1.300^{* * *} \\
(0.163)\end{array}$ & 0.768 & $-5.13(0)^{++}$ \\
\hline Venezuella & $\begin{array}{l}3.884 * * \\
(0.111)\end{array}$ & $\begin{array}{l}-0.014 * \\
(0.008)\end{array}$ & $\begin{array}{l}0.282 * * \\
(0.027)\end{array}$ & $\begin{array}{l}0.635^{* *} \\
(0.017)\end{array}$ & $\begin{array}{l}-0.907 * * \\
(0.037)\end{array}$ & 0.872 & $-3.80(0)^{++}$ \\
\hline
\end{tabular}


Table 3. Panel Unit Root Tests

\begin{tabular}{|c|c|c|c|}
\hline Variables & MW & LLC & IPS \\
\hline $\mathbf{S}$ & $\begin{array}{c}11.59(4) \\
{[1.000]}\end{array}$ & $\begin{array}{l}3.38(4) \\
{[1.000]}\end{array}$ & $\begin{array}{l}3.61(4) \\
{[0.999]}\end{array}$ \\
\hline$\Delta \mathbf{s}$ & $\begin{array}{c}3705.0^{++}(3) \\
(0.000)\end{array}$ & $\begin{array}{c}-101.1^{++}(3) \\
(0.000)\end{array}$ & $\begin{array}{c}-103.7^{++}(3) \\
(0.000)\end{array}$ \\
\hline rt & $\begin{array}{c}27.05(0) \\
{[0.859]}\end{array}$ & $\begin{array}{c}0.170(0) \\
{[0.567]}\end{array}$ & $\begin{array}{c}-0.838(0) \\
{[0.201]}\end{array}$ \\
\hline$\Delta \mathrm{rt}$ & $\begin{array}{c}187.2^{++}(0) \\
{[0.000]}\end{array}$ & $\begin{array}{c}-194.0^{++}(0) \\
{[0.000]}\end{array}$ & $\begin{array}{c}-157.5^{++}(0) \\
{[0.000]}\end{array}$ \\
\hline vix & $\begin{array}{c}31.94(3) \\
{[0.663]}\end{array}$ & & \\
\hline$\Delta$ vix & $\begin{array}{c}2442.7^{++}(2) \\
0.000]\end{array}$ & & \\
\hline hys & $\begin{array}{c}31.61(2) \\
{[0.680]}\end{array}$ & & \\
\hline$\Delta$ hys & $\begin{array}{c}832.1^{++}(1) \\
{[0.000]}\end{array}$ & & \\
\hline fdtr & $\begin{array}{c}21.52(0) \\
{[0.973]}\end{array}$ & & \\
\hline$\Delta$ fdtr & $\begin{array}{c}331.6^{++}(0) \\
{[0.000]}\end{array}$ & & \\
\hline \multicolumn{4}{|c|}{$\begin{array}{l}\text { Notes: MW, LLC and IPS are the Maddala and Wu (1999), Levin, Li and } \\
\text { Chu (2002) and Im, Pesaran and Shin (2003) panel unit root tests, } \\
\text { respectively. We report the ( }\left(t^{*}\right) \text { statistic of LLC and W statistic of IPS. For } \\
\text { the global variables, the LLC and IPS tests are not considered as there is no } \\
\text { cross-sectional variation in the data. The values in brackets [.] are the p- } \\
\text { values and the optimum lag lengths for the tests, chosen by the AIC, are } \\
\text { presented in parantheses. }\left({ }^{+}\right) \text {and }\left({ }^{++}\right) \text {denote the rejection of the unit root } \\
\text { null at the 5\% and } 1 \% \text { levels, respectively. }\end{array}$} \\
\hline
\end{tabular}


Table 4. The Determinants of the EMBI Spreads:

Panel Data Estimations and Panel Cointegration

\begin{tabular}{|c|c|c|c|c|}
\hline & Equation 4.1 & Equation 4.2 & Equation 4.3 & Equation 4.4 \\
\hline constant & $\begin{array}{c}3.092 * * \\
(0.018)\end{array}$ & $\begin{array}{c}6.452 * * \\
(0.089)\end{array}$ & $\begin{array}{c}3.293 * * \\
(0.020)\end{array}$ & $\begin{array}{c}1.180 * * \\
(0.044)\end{array}$ \\
\hline rt & $\begin{array}{c}-0.435^{* *} * \\
(0.002)\end{array}$ & $\begin{array}{c}-0.449 * * \\
(0.003)\end{array}$ & $\begin{array}{c}-0.433 * * \\
(0.003)\end{array}$ & $\begin{array}{c}-0.422 * * \\
(0.002)\end{array}$ \\
\hline vix & $\begin{array}{l}1.287 * * \\
(0.006)\end{array}$ & & $\begin{array}{l}1.189 * * \\
(0.007)\end{array}$ & $\begin{array}{c}0.167 * * \\
(0.010)\end{array}$ \\
\hline hys & & $\begin{array}{l}1.306 * * \\
(0.011)\end{array}$ & $\begin{array}{c}0.234 * * \\
(0.011)\end{array}$ & \\
\hline m_S & & & & $\begin{array}{c}0.793 * * \\
(0.006)\end{array}$ \\
\hline m_rt & & & & $\begin{array}{l}0.202 * * \\
(0.013)\end{array}$ \\
\hline $\mathrm{N}$ & 33751 & 33751 & 33751 & 33751 \\
\hline $\mathrm{R}^{2}$ & 0.857 & 0.748 & 0.819 & 0.903 \\
\hline Pedroni & $\begin{array}{c}-10.03^{++} \\
{[0.000]}\end{array}$ & $\begin{array}{c}-4.590^{++} \\
{[0.000]}\end{array}$ & $\begin{array}{l}-8.16^{++} \\
{[0.000]}\end{array}$ & $\begin{array}{l}-4.60^{++} \\
{[0.000]}\end{array}$ \\
\hline Kao & $\begin{array}{c}-7.027^{++} \\
{[0.000]}\end{array}$ & $\begin{array}{l}-1.955^{+} \\
{[0.025]}\end{array}$ & $\begin{array}{l}-6.49^{++} \\
{[0.000]}\end{array}$ & $\begin{array}{l}-6.17^{++} \\
{[0.000]}\end{array}$ \\
\hline IPS & $\begin{array}{c}-15.17^{++} \\
{[0.000]}\end{array}$ & $\begin{array}{c}-2.726^{++} \\
{[0.003]}\end{array}$ & $\begin{array}{c}-14.39^{++} \\
{[0.000]}\end{array}$ & $\begin{array}{l}-7.48^{++} \\
{[0.000]}\end{array}$ \\
\hline
\end{tabular}

Notes. t-ratios in parentheses. $(* *)$ denotes significance at the $1 \%$ level. Pedroni and Kao are the panel ADF statistics to test the null of no panel cointegration proposed by Pedroni (2004) and Kao (1999), respectively. IPS is the Im, Pesaran and Shin (2003) panel unit root test for the equation residuals. The optimum lag lengths for the tests are chosen by the AIC. The values in brackets [.] are the p-values. (++ ) and (+) denote the rejection of the null of no cointegration at the $1 \%$ and $5 \%$ levels, respectively. 
Table 5. Panel ECM Estimations and US Macroeconomic News

\begin{tabular}{|c|c|c|c|c|}
\hline & $(5.1)$ & $(5.2)$ & \multicolumn{2}{|c|}{ (5.3) } \\
\hline constant & $\begin{array}{c}-0.0007 * * \\
(0.0002)\end{array}$ & $\begin{array}{c}-0.0007 * * \\
(0.0002)\end{array}$ & $\begin{array}{c}-0.0007 * * \\
(0.0002)\end{array}$ & \\
\hline$e c_{t-1}$ & $\begin{array}{c}-0.0074 * * \\
(0.0006)\end{array}$ & $\begin{array}{c}-0.0073 * * \\
(0.0006)\end{array}$ & $\begin{array}{c}-0.0073 * * \\
(0.0006)\end{array}$ & \\
\hline$\Delta \mathbf{s}_{\mathrm{t}-1}$ & $\begin{array}{c}-0.1667 * * \\
(0.0053)\end{array}$ & $\begin{array}{c}-0.1672 * * \\
(0.0053)\end{array}$ & $\begin{array}{c}-0.1672 * * \\
(0.0053)\end{array}$ & \\
\hline$\Delta \mathbf{r t}_{\mathbf{t}}$ & $\begin{array}{c}-0.0003 \\
(0.0038)\end{array}$ & $\begin{array}{c}-0.0005 \\
(0.0038)\end{array}$ & $\begin{array}{l}-0.0005 \\
(0.0038)\end{array}$ & \\
\hline$\Delta \mathbf{r t}_{\mathrm{t}-1}$ & $\begin{array}{c}0.0028 \\
(0.0038)\end{array}$ & $\begin{array}{c}0.0027 \\
(0.0038)\end{array}$ & $\begin{array}{c}0.0026 \\
(0.0038)\end{array}$ & \\
\hline$\Delta$ vix $_{t}$ & $\begin{array}{c}0.1197 * * \\
(0.0042)\end{array}$ & $\begin{array}{c}0.1185^{* *} * \\
(0.0042)\end{array}$ & $\begin{array}{c}0.1191 * * \\
(0.0042)\end{array}$ & \\
\hline$\Delta \operatorname{vix}_{t-1}$ & $\begin{array}{c}0.0598 * * \\
(0.0043)\end{array}$ & $\begin{array}{c}0.0601 * * \\
(0.0043)\end{array}$ & $\begin{array}{c}-0.0598 * * \\
(0.0043)\end{array}$ & \\
\hline$\Delta \mathbf{f d t r}_{t}$ & & $\begin{array}{c}0.0089 \\
(0.0137)\end{array}$ & $\begin{array}{c}0.0077 \\
(0.0137)\end{array}$ & \\
\hline$\Delta \mathbf{f d t r}_{\mathrm{t}-1}$ & & $\begin{array}{c}0.0307 * * \\
(0.0137)\end{array}$ & $\begin{array}{c}0.0289 * * \\
(0.0136)\end{array}$ & \\
\hline & & News & News & D*News \\
\hline NFP & & $\begin{array}{c}-0.2373 * * \\
(0.1023)\end{array}$ & $\begin{array}{c}-0.4330 * * \\
(0.1296)\end{array}$ & $\begin{array}{c}0.4967 * * \\
(0.2103)\end{array}$ \\
\hline MAN & & $\begin{array}{c}-1.4045^{* *} \\
(0.1026)\end{array}$ & $\begin{array}{c}-2.1722 * * \\
(0.1315)\end{array}$ & $\begin{array}{l}1.9459 * * \\
(0.2098)\end{array}$ \\
\hline RS & & $\begin{array}{c}-0.3507 * * \\
(0.0999)\end{array}$ & $\begin{array}{c}-0.3584 * * \\
(0.1303)\end{array}$ & $\begin{array}{c}0.0191 \\
(0.1303)\end{array}$ \\
\hline NHS & & $\begin{array}{c}-0.1865^{* *} \\
(0.0978)\end{array}$ & $\begin{array}{c}-0.5208^{* * *} \\
(0.1212)\end{array}$ & $\begin{array}{c}0.8879 * * \\
(0.2056)\end{array}$ \\
\hline CCONF & & $\begin{array}{c}-0.1912 * * \\
(0.1024)\end{array}$ & $\begin{array}{c}0.1593 \\
(0.1454)\end{array}$ & $\begin{array}{c}-0.6371 * * \\
(0.2048)\end{array}$ \\
\hline $\mathrm{N}$ & 33713 & 33644 & & 33644 \\
\hline $\mathrm{R}^{2}$ & 0.055 & 0.061 & & 0.064 \\
\hline DW & 2.02 & 2.01 & & 2.01 \\
\hline $\mathrm{F}$ & 85.7 & 72.9 & & 66.1 \\
\hline $\begin{array}{l}\text { Notes: } 1 \text {. See } \\
\text { 2. In equation } \\
\text { correspondin } \\
\text { 3. The coeffic } \\
\text { the ease of in }\end{array}$ & $\begin{array}{l}f \text { the news } \\
\text { tion. }\end{array}$ & $\begin{array}{l}\text { es by the infle } \\
\text { es and their st }\end{array}$ & $\begin{array}{l}\text { errors are } \mathrm{m} \\
\text { minace du }\end{array}$ & $\begin{array}{l}\text { tts of the } \\
\text { riable } D \text {. } \\
\text { by } 100 \text { for }\end{array}$ \\
\hline
\end{tabular}


Table 6. US Macroeconomic Announcements

\begin{tabular}{|c|c|c|c|c|c|}
\hline \multirow[t]{2}{*}{ Announcement } & \multirow[t]{2}{*}{$\mathbf{N}$} & \multirow[t]{2}{*}{ Source } & \multicolumn{3}{|c|}{ ADF Tests } \\
\hline & & & Realized & Expected & Surprise \\
\hline \multicolumn{6}{|l|}{ Real Activity } \\
\hline Nonfarm Payroll Employment (NFP) & 108 & BLS & $-5.65 * *$ & $-3.53 * *$ & $-8.82 * *$ \\
\hline Retail Sales (RS) & 90 & $\mathrm{BC}$ & $-13.54 * *$ & $-8.88 * *$ & $-14.93 * *$ \\
\hline Capacity Utilization (CU) & 108 & FRB & $\begin{array}{l}-1.29 \\
{[-8.79 * *]}\end{array}$ & $\begin{array}{l}-1.42 \\
{[-7.07 * *]}\end{array}$ & $-10.75^{* *}$ \\
\hline \multicolumn{6}{|l|}{ Consumption } \\
\hline New Home Sales (NHS) & 108 & $\mathrm{BC}$ & $\begin{array}{l}-2.98 \\
{[-13.94 * *]}\end{array}$ & $\begin{array}{l}-2.12 \\
{[-11.30 * *]}\end{array}$ & $-11.29 * *$ \\
\hline \multicolumn{6}{|l|}{ Forward Looking } \\
\hline ISM Manufacturing Index (MAN) & 104 & ISM & $\begin{array}{l}-2.33 \\
{[-9.29 * *]}\end{array}$ & $\begin{array}{l}-1.98 \\
{\left[-9.46^{* *}\right]}\end{array}$ & $-9.69^{* *}$ \\
\hline Consumer Confidence Index (CCONF) & 108 & $\mathrm{BC}$ & $\begin{array}{l}-1.71 \\
{[-10.20 * *]}\end{array}$ & $\begin{array}{l}-1.82 \\
{[-8.12 * *]}\end{array}$ & $-10.20 * *$ \\
\hline Index of Leading Indicators (LEAD) & 98 & $\mathrm{BC}$ & $-9.90 * *$ & $-8.26^{* *}$ & $-9.85 * *$ \\
\hline \multicolumn{6}{|l|}{ Prices (core) } \\
\hline Consumer Price Index (CPI) & 104 & BLS & $-9.79 * *$ & $-4.01 * *$ & $-9.41 * *$ \\
\hline Producer Price Index (PPI) & 104 & BLS & $-15.02 * *$ & $-7.40 * *$ & $-15.49 * *$ \\
\hline \multicolumn{6}{|c|}{$\begin{array}{l}\text { Notes and abbreviations: Number of observations (N), Bureau of Labor Statistics (BLS), Bureau of the } \\
\text { Census (BC), Federal Reserve Board (FRB), The Institute for Supply Management (ISM). ** Denotes the } \\
\text { rejection of the unit root null at the } 1 \% \text { level. The values in brackets [.] are the Dickey-Fuller (DF) test results } \\
\text { for the first difference of the corresponding variable. The optimum lag for the DF regression equations with no } \\
\text { constant is found to be zero for all the variables by the Akaike Information Criteria. The unit root test results } \\
\text { are found to be robust to both an inclusion of a constant term or a higher lag length. }\end{array}$} \\
\hline
\end{tabular}




\section{REFERENCES}

Afonso, A., Gomes, P. and P. Rother (2007) What 'hides' behind sovereign debt ratings?, European Central Bank, Working Paper No. 711.

Andersen, T.G., Bollerslev, T., Diebold, F.X. and C. Vega (2003) Micro effects of macro announcements: Real-time price discovery in foreign exchange, American Economic Review, 93, 38-62.

Andersen, T.G., Bollerslev, T., Diebold, F.X. and C. Vega (2007) Real-time price discovery in global stock, bond and foreign exchange markets, Journal of International Economics, 73, 251-277.

Andritzky, J.R., Bannister, G.J. and N.T. Tamirisa (2007) The impact of macroeconomic announcements on emerging market bonds, Emerging Markets Review, 8, 20-37.

Arora, V. and M. Cerisola (2001) How does US monetary policy influence sovereign spreads in emerging markets? IMF Staff Papers, 48, 474-498.

Balduzzi, P., Elton, E.J. and T.C. Green (2001) Economic news and bond prices: evidence from the US treasury market., Journal of Financial and Quantitative Analysis, 36, 523-543.

Blanchard, O. (2004) Fiscal dominance and inflation targeting: lessons from Brazil, NBER Working Paper No. 10389.

Boyd, J.H., Jagannathan, R. and J. Hu (2005) The stock market's reaction to unemployment news: Why bad news is usually good for stocks, Journal of Finance, 60, 649-672.

Broner, F.A.R., Gelos, G. and C.M. Reinhart (2006) When in peril, retrench: Testing the portfolio channel of contagion, Journal of International Economics, 6(1), 203-230.

Calvo, G.A. (2002) Globalization hazard and development reform in emerging markets, Economia, 2, 1-29.

Calvo, G.A. (2005) Crisis in emerging market economies: A global perspective, NBER Working Paper No. 11305.

Cantor, R. and F. Packer (1996) Determinants and impact of sovereign credit ratings, Federal Reserve Bank of New York Economic Policy Review, October, 37-53.

Clarida, R. and D. Waldman (2007) Is bad news about inflation good news for the exchange rate?, NBER Working Paper No. 13010.

Cline, W.R. and K.J.S. Barnes (1997) Spreads and risk in emerging market lending, IIF Research Paper No. 97-1.

Coakley, J., Fuertes A.M. and R. Smith (2006) Unobserved heterogeneity in panel time series models, Computational Statistics \& Data Analysis, 50, 2362-2380.

Çulha, O.Y., Özatay; F. and G. Şahinbeyoğlu (2006) The determinants of sovereign spreads in emerging markets, Central Bank of Turkey, Research and Monetary Policy Department, Working Paper No. 06/04.

Dailami, M., Masson, P. and J.J. Padou (2005) Global monetary conditions versus countryspecific factors in the determination of emerging market debt spreads, Policy Research Working Paper 3626, Washington: World Bank.

Edison, H.J. (1997) The reaction of exchange rates and interest rates to news releases, International Journal of Finance and Economics, 2, 87-100.

Eichengreen, B. and A. Mody (1998) Interest rates in the north and capital flows to the south: Is there a missing link? International Finance, 1, 35-57. 
Eichengreen, B. and A. Mody (2000) What explains changing spreads on emerging-market debt: fundamentals or market sentiment? In: Edwards, S. (Ed.), The Economics of International Capital Flows, Chicago University Press.

Engle, R. and C.W.J. Granger (1987) Cointegration and error correction: Representation, estimation, and testing, Econometrica, 55(2), 251-76.

Faust, J., Rogers, J.A., Wang, S-Y. and J.H. Wright (2007) The high-frequency response of exchange rates and interest rates to macroeconomic announcements, Journal of Monetary Economics, 54, 1051-1068.

Favero, C.A. and F. Giavazzi (2004) Inflation targeting and debt: Lessons from Brazil, NBER Working Paper No. 10390.

Fostel, A. and G.L. Kaminsky (2007) Latin America's access to international capital markets: Good behavior or global liquidity? NBER Working Paper No. 13194.

Gande, A. and D.C. Parsley (2005) News spillovers in the sovereign debt market, Journal of Financial Economics, 75, 691-734.

García-Herrero, A. and A. Ortíz (2006) The role of global risk aversion in explaining Latin American sovereign spreads, Economia, 7(1), 125-148.

Gonzales-Rozada, M. and E. Levy-Yeyati (2006) Global factors and emerging market spreads, Inter-American Development Bank Working Paper No. 552.

Gürkaynak, R., Sack, B. and E. Swanson (2005) The sensitivity of long-term interest rates to economic news: Evidence and implications for macroeconomic models, American Economic Review, 95(1), 425-436.

Im, K. S., Pesaran, M. H., and Y. Shin (2003) Testing for Unit Roots in Heterogeneous Panels," Journal of Econometrics, 115, 53-74.

Izquierdo, A., Romero, R. and E. Talvi (2007) Business cycles in Latin America: The role of external factors, Mimeo, Inter-American Development Bank.

JPMorgan (2004) Emerging markets bond index plus (EMBI+): Rules and methodology, J.P. Morgan Securities Inc. Emerging Markets Research, December.

Kamin, S.B. (2002) Identfying the role of moral hazard in international financial markets. Board of Governors of the Federal Reserve System International Finance Discussion Paper No. 736.

Kamin, S.B. and K. von Kleist (1999) The evolution and determinants of emerging market credit spreads in the 1990s, BIS Working Paper No. 68.

Kaminsky, G.L., Reinhart, C. and C. A. Végh (2004) When it rains it pours: Procyclical capital flows and policies, in M. Gertler and K.S. Rogoff, eds. NBER Macroeconomics Annual 2004, Cambridge, Mass: MIT Press, 11-53.

Kaminsky, G.L. and S.L. Schmukler (1999) What triggers market jitters? A chronicle of the Asian crisis, Journal of International Money and Finance, 18, 537-560.

Kao, C. (1999) Spurious regression and residual-based tests for cointegration in panel data, Journal of Econometrics, 90 , 1-44.

Kapetanios, G., and Pesaran, M.H. (2007), Alternative approaches to estimation and inference in large multifactor panels: Small sample results with an application to modelling of asset returns, in Phillips, G., Tzavalis, E. (Eds.,), The Refinement of Econometric Estimation and Test Procedures: Finite Sample and Asymptotic Analysis, Cambridge University Press, Cambridge.

Levin, A., Lin, C. F., and C. Chu (2002) Unit root tests in panel data: Asymptotic and finitesample properties, Journal of Econometrics, 108, 1-24. 
Mackowiak, B. (2007) External shocks, U.S. monetary policy and macroeconomic fluctuations in emerging markets, Journal of Monetary Economics, 54, 2512-2520.

Maddala, G. S. and S. Wu (1999) A Comparative Study of Unit Root Tests with Panel Data and A New Simple Test, Oxford Bulletin of Economics and Statistics, 61, 631-52.

McQueen, G. and V.V. Roley (1993) Stock prices, news and business conditions, The Review of Financial Studies, 6(3), 683-707.

Neumeyer, P.A. and F. Perri (2005) Business cycles in emerging economies: The role of interest rates, Journal of Monetary Economics, 52, 345-380.

Özatay, F. (2005) Monetary policy challenges for Turkey in European union accession process, in: Basçı, E., von Hagen, J., Togan, S. (Eds.), Macroeconomic Policies for EU Accession, Edward Elgar.

Pedroni, P. (2004) Panel cointegration; Asymptotic and finite sample properties of pooled time series tests with an application to the purchasing power parity hypothesis, Econometric Theory, 20, 597-325.

Pesaran, M.H. (2006) Estimation and inference in large heterogenous panels with multifactor error structure, Econometrica, 74, 967-1012.

Pesaran, M.H. and R. Smith (1995) Estimating long-run relationships from dynamic heterogeneous panels, Journal of Econometrics, 68, 79-113.

Phillips, P.C.B. and H.R. Moon (1999) Linear regression theory for nonstationary panel data, Econometrica, 67, 1057-1111.

Robitaille, P. and J. Roush (2006) How do FOMC actions and U.S. macroeconomic data announcements move Brazilian sovereign yield spreads and stock prices? Board of Governors of the Federal Reserve System, International Finance Discussion Papers No 868.

Uribe, M. and V.Z. Yue (2006) Country spreads and emerging countries: Who drives whom? Journal of International Economics, 69, 6-36.

Wongswan, J. (2006) Transmission of information across international equity markets, The Review of Financial Studies, 19(4), 1158-1189. 


\section{APPENDIX}

Table A1. ADF Tests for the Country-Specific Variables

\begin{tabular}{|l|l|l|l|l|}
\hline Country & \multicolumn{1}{|c|}{$\mathbf{s}_{\mathbf{t}}$} & \multicolumn{1}{|c|}{$\Delta \mathbf{s}_{\mathbf{t}}$} & $\mathbf{r}_{\mathbf{t}}$ & $\Delta \mathbf{r}_{\mathbf{t}}$ \\
\hline Argentina & $-1.13(13)$ & $-10.3(12)^{* *}$ & $-1.22(0)$ & $-47.3(0)^{* *}$ \\
\hline Brazil & $-0.59(1)$ & $-41.0(0)^{* *}$ & $-0.63(0)$ & $-47.4(0)^{* *}$ \\
\hline Bulgaria & $-0.15(3)$ & $-33.1(0)^{* *}$ & $-0.26(0)$ & $-45.1(0)^{* *}$ \\
\hline Colombia & $-0.48(0)$ & $-45.0(0)^{* *}$ & $-1.91(0)$ & $-47.4(0)^{* *}$ \\
\hline Ecuador & $-1.58(1)$ & $-43.8(1)^{* *}$ & $-1.08(0)$ & $-47.4(0)^{* *}$ \\
\hline Egypt & $-1.59(2)$ & $-29.8(0)^{* *}$ & $-0.63(0)$ & $-47.4(0)^{* *}$ \\
\hline Mexico & $-0.71(1)$ & $-43.4(0)^{* *}$ & $1.53(0)$ & $-47.3(0)^{* *}$ \\
\hline Malaysia & $-0.83(2)$ & $-27.4(1)^{* *}$ & $-0.22(0)$ & $-47.3(0)^{* *}$ \\
\hline Morocco & $-0.47(3)$ & $-37.7(2)^{* *}$ & $-1.06(0)$ & $-46.9(0)^{* *}$ \\
\hline Panama & $-0.73(0)$ & $-47.9(0)^{* *}$ & $-0.80(0)$ & $-47.4(0)^{* *}$ \\
\hline Peru & $-0.43(1)$ & $-33.1(0)^{* *}$ & $-0.26(0)$ & $-45.1(0)^{* *}$ \\
\hline Philliphines & $-0.59(1)$ & $-53.7(0)^{* *}$ & $0.58(0)$ & $-47.3(0)^{* *}$ \\
\hline Poland & $-1.06(3)$ & $-39.1(2)^{* *}$ & $-2.03(0)$ & $-47.4(0)^{* *}$ \\
\hline Russia & $-0.23(0)$ & $-46.9(0)^{* *}$ & $-1.42(0)$ & $-47.3(0)^{* *}$ \\
\hline S. Africa & $-2.15(0)$ & $-30.7(0)^{* *}$ & $-0.33(0)$ & $-47.4(0)^{* *}$ \\
\hline Turkey & $-0.62(0)$ & $-41.5(0)^{* *}$ & $-0.93(0)$ & $-47.3(0)^{* *}$ \\
\hline Ukraine & $-2.06(1)$ & $-47.5(0)^{* *}$ & $-0.50(0)$ & $-35.4(0)^{* *}$ \\
\hline Venezuella & $-0.37(1)$ & $-43.9(0)^{* *}$ & $-0.67(0)$ & $-47.3(0)^{* *}$ \\
\hline $\begin{array}{l}\text { Notes: The values in parentheses are the optimum lag length for the ADF } \\
\text { regessions chosen by the AIC. }(* *) \text { denotes the rejection of the unit root } \\
\text { null hypothesis at the 1\% level }\end{array}$ & & & \\
\hline
\end{tabular}


Table A2. The Determinants of EMBI Spreads: Country Estimates with hys

\begin{tabular}{|c|c|c|c|c|c|}
\hline Country & constant & rt & hys & $\mathbf{R}^{2}$ & ADF(I) \\
\hline Argentina & $\begin{array}{l}7.410 * * \\
(0.014)\end{array}$ & $\begin{array}{l}-0.569 * * \\
(0.004)\end{array}$ & $\begin{array}{l}0.705^{* *} \\
(0.031)\end{array}$ & 0.904 & $-4.90(0)^{++}$ \\
\hline Brazil & $\begin{array}{l}18.103 * * \\
(0.194)\end{array}$ & $\begin{array}{l}-5.265 * * \\
(0.084)\end{array}$ & $\begin{array}{l}0.747 * * \\
(0.025)\end{array}$ & 0.749 & $-3.50(0)^{+}$ \\
\hline Bulgaria & $\begin{array}{l}14.699 * * \\
(0.070)\end{array}$ & $\begin{array}{l}-3.948 * * \\
(0.026)\end{array}$ & $\begin{array}{l}0.930 * * \\
(0.023)\end{array}$ & 0.967 & $-4.37(2)^{++}$ \\
\hline Colombia & $\begin{array}{l}5.564 * * \\
(0.427)\end{array}$ & $\begin{array}{l}-0.048 \\
(0.176)\end{array}$ & $\begin{array}{l}1.389 * * \\
(0.036)\end{array}$ & 0.477 & $-1.99(0)$ \\
\hline Ecuador & $\begin{array}{l}6.334 * * \\
(0.175) \\
\end{array}$ & $\begin{array}{l}0.018 \\
(0.096) \\
\end{array}$ & $\begin{array}{l}1.292 * * \\
(0.026)\end{array}$ & 0.607 & $-3.06(0)$ \\
\hline Egypt & $\begin{array}{l}42.110 * * \\
(1.962)\end{array}$ & $\begin{array}{l}-15.519 * * \\
(0.797)\end{array}$ & $\begin{array}{l}4.119 * * \\
(0.081)\end{array}$ & 0.693 & $-3.43(1)^{+}$ \\
\hline Mexico & $\begin{array}{l}20.887 * * \\
(0.128)\end{array}$ & $\begin{array}{l}-6.097 * * \\
(0.050)\end{array}$ & $\begin{array}{l}0.571^{* *} \\
(0.016)\end{array}$ & 0.888 & $-4.26(0)^{++}$ \\
\hline Malaysia & $\begin{array}{l}13.813 * * \\
(0.500)\end{array}$ & $\begin{array}{l}-3.975 * * \\
(0.164)\end{array}$ & $\begin{array}{l}0.570^{* *} \\
(0.023)\end{array}$ & 0.830 & $-3.94(1)^{++}$ \\
\hline Morocco & $\begin{array}{l}39.739 * * \\
(0.657)\end{array}$ & $\begin{array}{l}-14.211 * * \\
(0.269)\end{array}$ & $\begin{array}{l}0.574 * * \\
(0.042)\end{array}$ & 0.702 & $-3.53(0)^{+}$ \\
\hline Panama & $\begin{array}{l}0.950 * * \\
(0.252)\end{array}$ & $\begin{array}{l}1.946 * * \\
(0.105)\end{array}$ & $\begin{array}{l}0.572^{* *} \\
(0.022)\end{array}$ & 0.398 & $-1.65(0)$ \\
\hline Peru & $\begin{array}{l}11.702 * * \\
(0.360)\end{array}$ & $\begin{array}{l}-2.540 * * \\
(0.150)\end{array}$ & $\begin{array}{l}0.959 * * \\
(0.033)\end{array}$ & 0.475 & $-4.00(0)^{++}$ \\
\hline Philliphines & $\begin{array}{l}2.232 * * \\
(0.199)\end{array}$ & $\begin{array}{l}1.527 \\
(0.084)\end{array}$ & $\begin{array}{l}0.344 * * \\
(0.025)\end{array}$ & 0.331 & $-0.59(0)$ \\
\hline Poland & $\begin{array}{l}31.678 * * \\
(0.466)\end{array}$ & $\begin{array}{l}-10.291 * * \\
(0.175)\end{array}$ & $\begin{array}{l}2.223 * * \\
(0.032)\end{array}$ & 0.744 & $-4.68(1)^{++}$ \\
\hline Russia & $\begin{array}{l}6.539 * * \\
(0.039) \\
\end{array}$ & $\begin{array}{l}-0.393^{* *} \\
(0.010) \\
\end{array}$ & $\begin{array}{l}0.853 * * \\
(0.079)\end{array}$ & 0.525 & $-1.70(1)$ \\
\hline S. Africa & $\begin{array}{l}19.970 * * \\
(0.349)\end{array}$ & $\begin{array}{l}-5.819 * * \\
(0.130)\end{array}$ & $\begin{array}{l}0.951 * * \\
(0.040)\end{array}$ & 0.763 & $-4.15(1)^{++}$ \\
\hline Turkey & $\begin{array}{l}10.664 * * \\
(0.083)\end{array}$ & $\begin{array}{l}-2.257 * * \\
(0.036)\end{array}$ & $\begin{array}{l}0.727 * * \\
(0.025)\end{array}$ & 0.857 & $-3.61(0)^{+}$ \\
\hline Ukraine & $\begin{array}{l}10.474 * * \\
(0.189)\end{array}$ & $\begin{array}{l}-2.409 * * \\
(0.083)\end{array}$ & $\begin{array}{l}1.468^{* *} \\
(0.045)\end{array}$ & 0.796 & $-5.21(0)^{++}$ \\
\hline Venezuella & $\begin{array}{l}6.278 * * \\
(0.040)\end{array}$ & $\begin{array}{l}-0.120 * * \\
(0.019)\end{array}$ & $\begin{array}{l}1.329 * * \\
(0.040)\end{array}$ & 0.329 & $-1.41(0)$ \\
\hline
\end{tabular}


Table A3. The Determinants of EMBI Spreads: CCE Country Estimates with hys

\begin{tabular}{|c|c|c|c|c|c|c|c|}
\hline Country & constant & rt & hys & $\mathbf{m} \_\mathbf{s}$ & m_rrt & $\mathbf{R}^{2}$ & ADF(l) \\
\hline Argentina & $\begin{array}{l}4.754 * * \\
(0.180)\end{array}$ & $\begin{array}{l}-0.583 * * \\
(0.004)\end{array}$ & $\begin{array}{l}-0.016 \\
(0.029)\end{array}$ & $\begin{array}{l}0.505 * * \\
(0.014)\end{array}$ & $\begin{array}{l}-0.056 \\
(0.058)\end{array}$ & 0.947 & $-5.14(8)^{++}$ \\
\hline Brazil & $\begin{array}{l}10.431 * * \\
(0.224)\end{array}$ & $\begin{array}{l}-3.547 * * \\
(0.104)\end{array}$ & $\begin{array}{l}0.247 * * \\
(0.021)\end{array}$ & $\begin{array}{l}0.528 * * \\
(0.011)\end{array}$ & $\begin{array}{l}0.350^{* * *} \\
(0.044)\end{array}$ & 0.888 & $-3.73(2)^{++}$ \\
\hline Bulgaria & $\begin{array}{l}9.993 * * \\
(0.290)\end{array}$ & $\begin{array}{l}-3.214 * * \\
(0.055)\end{array}$ & $\begin{array}{l}0.706 * * \\
(0.026)\end{array}$ & $\begin{array}{l}0.366 * * \\
(0.022)\end{array}$ & $\begin{array}{l}0.378^{* *} \\
(0.035)\end{array}$ & 0.971 & $\begin{array}{l}-4.57(1)^{+} \\
+\end{array}$ \\
\hline Colombia & $\begin{array}{l}4.260 * * \\
(0.222)\end{array}$ & $\begin{array}{l}-0.343 * * \\
(0.089)\end{array}$ & $\begin{array}{l}0.476^{* * *} \\
(0.032)\end{array}$ & $\begin{array}{l}0.493 * * \\
(0.015)\end{array}$ & $\begin{array}{l}-0.205^{* *} \\
(0.038)\end{array}$ & 0.863 & $-5.52(0)^{++}$ \\
\hline Ecuador & $\begin{array}{l}3.477 * * \\
(0.146)\end{array}$ & $\begin{array}{l}-0.164 * * \\
(0.008)\end{array}$ & $\begin{array}{l}0.041 \\
(0.031)\end{array}$ & $\begin{array}{l}0.637^{* *} \\
(0.016)\end{array}$ & $\begin{array}{l}0.029 \\
(0.036)\end{array}$ & 0.888 & $-3.66(0)^{++}$ \\
\hline Egypt & $\begin{array}{l}5.480 * * \\
(1.623)\end{array}$ & $\begin{array}{l}-2.805 * * \\
(0.713)\end{array}$ & $\begin{array}{l}1.483 * * \\
(0.092)\end{array}$ & $\begin{array}{l}1.017 * * \\
(0.049)\end{array}$ & $\begin{array}{l}0.075 \\
(0.142)\end{array}$ & 0.870 & $-4.71(0)^{++}$ \\
\hline Mexico & $\begin{array}{l}6.776 \\
(0.312)\end{array}$ & $\begin{array}{l}-2.422 * * \\
(0.095)\end{array}$ & $\begin{array}{l}-0.064 * * \\
(0.019)\end{array}$ & $\begin{array}{l}0.632^{* * *} \\
(0.015)\end{array}$ & $\begin{array}{l}0.555^{* *} \\
(0.023)\end{array}$ & 0.933 & $-6.15(3)^{++}$ \\
\hline Malaysia & $\begin{array}{l}0.690 \\
(0.672)\end{array}$ & $\begin{array}{l}-0.980 * * \\
(0.190)\end{array}$ & $\begin{array}{l}0.020 \\
(0.054)\end{array}$ & $\begin{array}{l}0.936^{* *} \\
(0.028)\end{array}$ & $\begin{array}{l}0.493 \\
(0.268)\end{array}$ & 0.939 & $-5.77(0)^{++}$ \\
\hline Morocco & $\begin{array}{l}1.596 \\
(0.395)\end{array}$ & $\begin{array}{l}-1.605^{* *} \\
(0.155)\end{array}$ & $\begin{array}{l}-0.203^{* *} \\
(0.015)\end{array}$ & $\begin{array}{l}1.236^{* *} \\
(0.010)\end{array}$ & $\begin{array}{l}0.247^{* * *} \\
(0.026)\end{array}$ & 0.967 & $-6.08(2)^{++}$ \\
\hline Panama & $\begin{array}{l}3.813^{* * *} \\
(0.153)\end{array}$ & $\begin{array}{l}-0.771 * * \\
(0.092)\end{array}$ & $\begin{array}{l}0.152 * * \\
(0.014)\end{array}$ & $\begin{array}{l}0.589^{* *} \\
(0.009)\end{array}$ & $\begin{array}{l}0.117^{*} \\
(0.028)\end{array}$ & 0.876 & $-6.16(3)^{++}$ \\
\hline Peru & $\begin{array}{l}3.964 \\
(0.161)\end{array}$ & $\begin{array}{l}-1.388 * * \\
(0.064) \\
\end{array}$ & $\begin{array}{l}0.202^{* *} \\
(0.015) \\
\end{array}$ & $\begin{array}{l}0.693 * * \\
(0.006) \\
\end{array}$ & $\begin{array}{l}0.492 * * \\
(0.023) \\
\end{array}$ & 0.916 & $-6.13(3)^{++}$ \\
\hline Philliphines & $\begin{array}{l}9.803 * * \\
(0.295)\end{array}$ & $\begin{array}{l}-3.069 * * \\
(0.151)\end{array}$ & $\begin{array}{l}0.029 \\
(0.022)\end{array}$ & $\begin{array}{l}0.703^{* *} \\
(0.021)\end{array}$ & $\begin{array}{l}-0.267 * * \\
(0.035)\end{array}$ & 0.571 & $-2.18(0)$ \\
\hline Poland & $\begin{array}{l}2.634 * * \\
(0.709)\end{array}$ & $\begin{array}{l}-2.095 * * \\
(0.215)\end{array}$ & $\begin{array}{l}0.624 * * \\
(0.042)\end{array}$ & $\begin{array}{l}0.966^{* * *} \\
(0.021)\end{array}$ & $\begin{array}{l}0.796^{* *} \\
(0.044)\end{array}$ & 0.871 & $-4.89(1)^{++}$ \\
\hline Russia & $\begin{array}{l}-7.583 * * \\
(0.156)\end{array}$ & $\begin{array}{l}-0.251 * * \\
(0.004)\end{array}$ & $\begin{array}{l}-0.654 * * \\
(0.032)\end{array}$ & $\begin{array}{l}1.592^{* *} \\
(0.015)\end{array}$ & $\begin{array}{l}2.209 * * \\
(0.051)\end{array}$ & 0.926 & $-4.53(1)^{++}$ \\
\hline S. Africa & $\begin{array}{l}-11.27 * * \\
(0.868)\end{array}$ & $\begin{array}{l}3.534 * * \\
(0.272)\end{array}$ & $\begin{array}{l}0.128 * * \\
(0.038)\end{array}$ & $\begin{array}{l}1.119^{* *} \\
(0.033)\end{array}$ & $\begin{array}{l}0.173^{* *} \\
(0.053)\end{array}$ & 0.900 & $-4.66(1)^{++}$ \\
\hline Turkey & $\begin{array}{l}6.505^{* *} \\
(0.210)\end{array}$ & $\begin{array}{l}-1.755^{* *} \\
(0.037)\end{array}$ & $\begin{array}{l}0.152 * * \\
(0.032)\end{array}$ & $\begin{array}{l}0.427^{* *} \\
(0.018)\end{array}$ & $\begin{array}{l}0.349^{* *} \\
(0.406)\end{array}$ & 0.894 & $-3.78(1)^{++}$ \\
\hline Ukraine & $\begin{array}{l}-3.284 * * \\
(0.407)\end{array}$ & $\begin{array}{l}1.182 * * \\
(0.136)\end{array}$ & $\begin{array}{l}0.670^{* * *} \\
(0.048)\end{array}$ & $\begin{array}{l}1.037 * * \\
(0.031)\end{array}$ & $\begin{array}{l}0.131 \\
(0.089)\end{array}$ & 0.903 & $-4.48(1)^{++}$ \\
\hline Venezuella & $\begin{array}{l}3.706^{* *} \\
(0.113)\end{array}$ & $\begin{array}{l}-0.012 \\
(0.009)\end{array}$ & $\begin{array}{l}0.007 \\
(0.023)\end{array}$ & $\begin{array}{l}0.785^{* *} \\
(0.010)\end{array}$ & $\begin{array}{l}-0.857 * * \\
(0.039)\end{array}$ & 0.866 & $-3.34(8)^{+}$ \\
\hline
\end{tabular}

